Article

\title{
Integrating Energy Efficiency into the Municipal Procurement Process of Buildings-Whose Responsibility?
}

\author{
Mihail Vinokurov*, Kaisa Grönman 『), Simo Hammo, Risto Soukka and Mika Luoranen \\ LUT School of Energy Systems, Lappeenranta University of Technology, FI-53851 Lappeenranta, Finland; \\ kaisa.gronman@lut.fi (K.G.); simo.hammo@lut.fi (S.H.); risto.soukka@lut.fi (R.S.); mika.luoranen@lut.fi (M.L.) \\ * Correspondence: mihail.vinokurov@lut.fi; Tel.: +35-850-449-1333
}

Received: 14 January 2019; Accepted: 11 February 2019; Published: 13 February 2019

\begin{abstract}
This study addresses the challenges in ensuring energy efficiency and high indoor climate quality with efficient use of public money in the municipal building procurement process. Energy efficient municipal building procurement provides a significant leverage when steering the built environment towards the low-carbon economy targets of the EU. Municipal building department professionals need more skills and knowledge to appropriately define the requirements and identify the energy efficient design options accounting for the building's changing operational environment. This study presents how to systematically integrate energy efficiency in the municipal procurement process of buildings by presenting the list of energy efficiency factors to be included into the procurement process. This list of factors clarifies how indoor climate quality, energy use, and the life cycle economy are related through technological solutions and how the optimal compromise solution can be determined. Furthermore, this list of factors explains the responsibilities in integrating energy efficiency within the municipal building procurement process. Applied in the design of the municipal building the list of factors contributes to more informed and transparent decision-making process.
\end{abstract}

Keywords: energy efficiency; indoor climate quality; life cycle economy; changing operational environment; municipal building procurement; climate targets

\section{Introduction}

Buildings are responsible for $40 \%$ of the energy consumption and $36 \%$ of greenhouse gas (GHG) emissions in the European Union (EU) [1]. Increasing the energy efficiency in buildings is recognized as an important policy objective in the EU for reaching the ambitious GHG emission reduction targets [2]. The Climate and Energy Framework of the EU for 2030 aims to reduce GHG emission reductions by $40 \%$ below the 1990 levels, to improve energy efficiency by $27 \%$, and to increase the share of renewables by $27 \%$ by 2030 [3]. For 2050, the EU targets to reach a low-carbon economy with GHG emissions cut to $80 \%$ below 1990 levels [3].

The Energy Efficiency Directive and the Energy Performance of Buildings Directive of the EU have established a set of binding measures to help the EU reach the required emission reductions cost efficiently. The directives request the public sector to procure energy efficient buildings without compromising the indoor climate quality and to do so with the efficient use of public money $[4,5]$. Public procurements correspond to $14 \%$ of the overall gross domestic product (GDP) off the EU $[2,6]$. Buildings are a major part of public procurements. With major purchasing power, municipalities have the potential to provide significant leverage when seeking to steer the building market towards energy efficiency improvements [7].

The building department of the municipality is responsible for providing the users spaces with the required functionality while using public money efficiently in the long term [8-10]. In the case of Finland, the municipal building department, the Department of Municipal Planning and Property 
Development, initiates and leads the building procurement project [9]. During the procurement process, the municipal building department uses local, national, and international energy efficiency strategies with project-specific requirements and targets while following the regulatory framework [11]. The national building codes of each EU member state provide the minimum energy performance requirements for building procurement projects $[12,13]$. In addition, each municipal building project has to fulfill the specific functional, economic, safety, cultural, and ecological requirements of the users $[10,14]$. The general requirements for a building are to provide heating, cooling, ventilation, and lighting so that safety and functionality requirements are met with efficient use of energy and costs $[8,10,14]$.

Despite the regulatory pressure to transit towards energy efficient municipal construction, the procurement of energy efficient and low-carbon buildings remains low [15]. Insufficient understanding of how to integrate energy efficiency into building procurement is among the barriers to sustainable municipal construction [15,16]. Municipal building department officers need more skills and knowledge to appropriately define requirements, qualify suppliers, and identify energy efficient design options $[10,15-17]$. Unclear responsibility distribution and inefficient communication between the municipal building department and the project partners jeopardizes the success of the project [18]. The municipal building department has to take active leadership over the procurement project to successfully implement energy efficient procurement [17]. Failing to do this during the design-related decisions can partially shift the decision-making ability of the building department to the designers and contractors, which often compromises the quality of the procured building $[10,19,20]$. There is a demand for clear guidelines defining how to integrate energy efficiency in the municipal building procurement project and what is the responsibility distribution in the project.

Energy efficiency must be addressed through the optimization of design solutions based on the useful output (such as indoor climate quality and GHG emission reductions) that the alternative solution provides with the specific energy input [21-24]. The optimal energy efficiency level may not always reduce energy demand if this is justified by the improved indoor climate quality. To achieve the EU targets, municipal building departments and designers require more clarity on how to holistically assess and optimize the building solutions with the goals of indoor climate quality and the efficient use of both energy and public money $[14,15,23,25]$. Holistic and systematic frameworks to describe the relationship between indoor climate quality, energy use, and the life cycle economy are needed to identify the optimal compromise design solution [14,24,25].

The tendency to concentrate on capital costs as the main criteria when selecting building design options is another barrier to achieving cost efficient emission reductions in municipal construction [15]. Investment costs typically constitute a quarter of the life cycle costs, while the majority of costs occur during the utilization of the building [15]. Up to four fifths of the total life cycle cost is fixed during the design phase (see Figure 1). The selection of the design solutions has to be based on more advanced, life cycle economy considerations to bring up the viability of the energy efficient design solutions along with the more efficient use of public money. In order to improve the life cycle economy of the building, the design has to accommodate the technological, economic, climatic, and regulatory changes in the building's operational environment in the long term [26]. Ongoing changes in the building's operational environment include decreasing costs of renewable energy technologies, increasing electricity market price volatility, emerging peak power fees, new kinds of demand-response options, and potential GHG reduction-oriented economic steering [27]. The feasibility assessments have to favor design solutions that respond to both present and to future circumstances with a low risk of becoming prematurely obsolete due to the high utilization costs [26,27]. The additional economic elements that need to be included in economic assessments were identified by [27]. The economic assessment should also include the monetizable benefits, such as indoor climate quality, derived from each design option [28]. In municipal service buildings, indoor climate quality can be monetized in the life cycle economy through externalities related to increased productivity and reduced employee sick leaves [29]. 


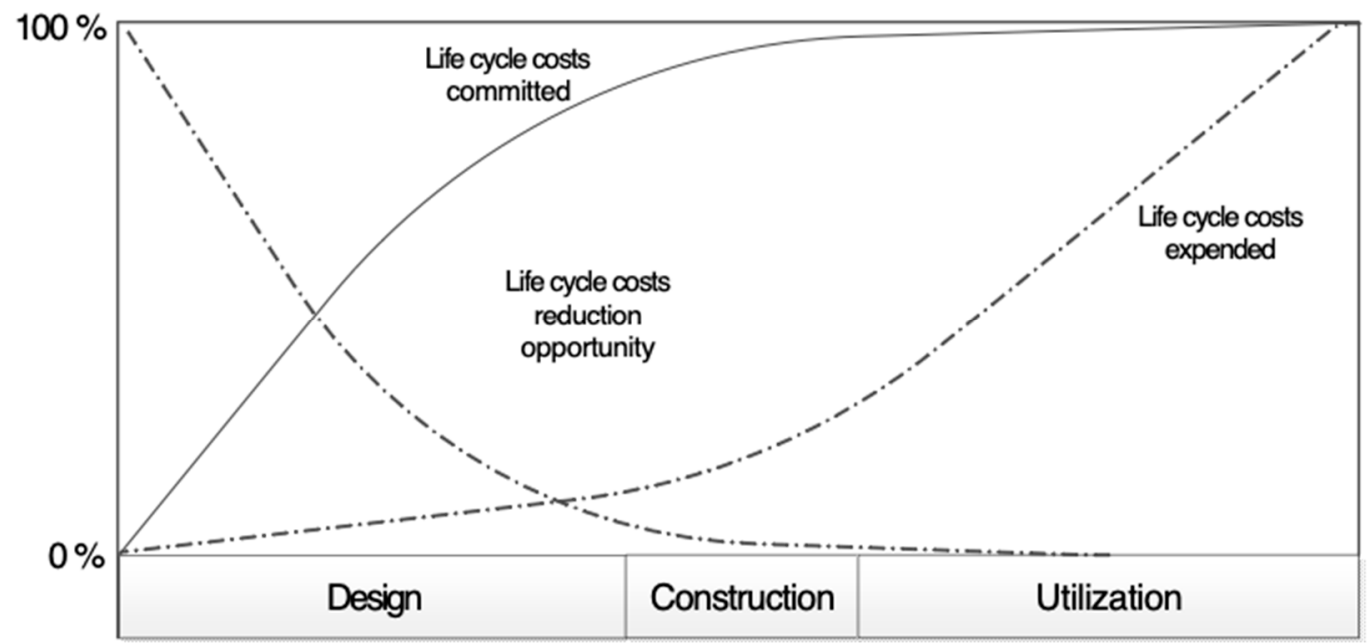

Figure 1. The general behavior of a commitment to life cycle costs [30-35].

This study presents how to systematically integrate energy efficiency into the municipal procurement process of buildings. The study clarifies the procurement process of energy efficient building by answering the following research questions:

- How should one describe energy efficiency factors in relation to the municipal building procurement process?

- What are the responsibilities of each actor at different stages of the municipal procurement process from an energy efficiency point of view?

The municipal building department is provided with a list of design factors that need to be considered when leading the procurement project towards energy efficiency and a high-quality indoor climate, which complies life cycle cost-effectively with international and national targets and regulations. Changes in the building's operational environment are given special emphasis in the list of energy efficiency factors. The list of factors points out which choices made in the design phase affect energy efficiency and clarifies the responsibilities in the building procurement process. Finnish municipal building procurement and building standards are used as an example of applying the list of factors, as these reflect the common EU regulations. The list of energy efficiency factors was developed alongside the actual procurement process of the local kindergarten by utilizing the experience of the municipal building department of the town of Lappeenranta, Finland.

\section{Methodology}

The step-by-step structure of the conducted research process and the methods applied in each step are presented in Figure 2.

As a starting point of the study, the procurement procedure of an energy efficient municipal building was identified systematically and was described with a review of the relevant literature. The phases of the procurement process were identified where the municipal building department can affect the realization of the energy efficiency. The relevant legislative frameworks providing the basic requirements for new building designs and the municipal procurement practices in EU and Finland were studied. The literature review also included the procurement-related documentation of the Finnish town Lappeenranta. Besides the literature review, the description of the procedure is based on the conversations with the municipal building procurement officers of Lappeenranta. The procedure was described by the phases of the procurement process, along with the phase-specific tasks, the outcomes, and the responsible players. 


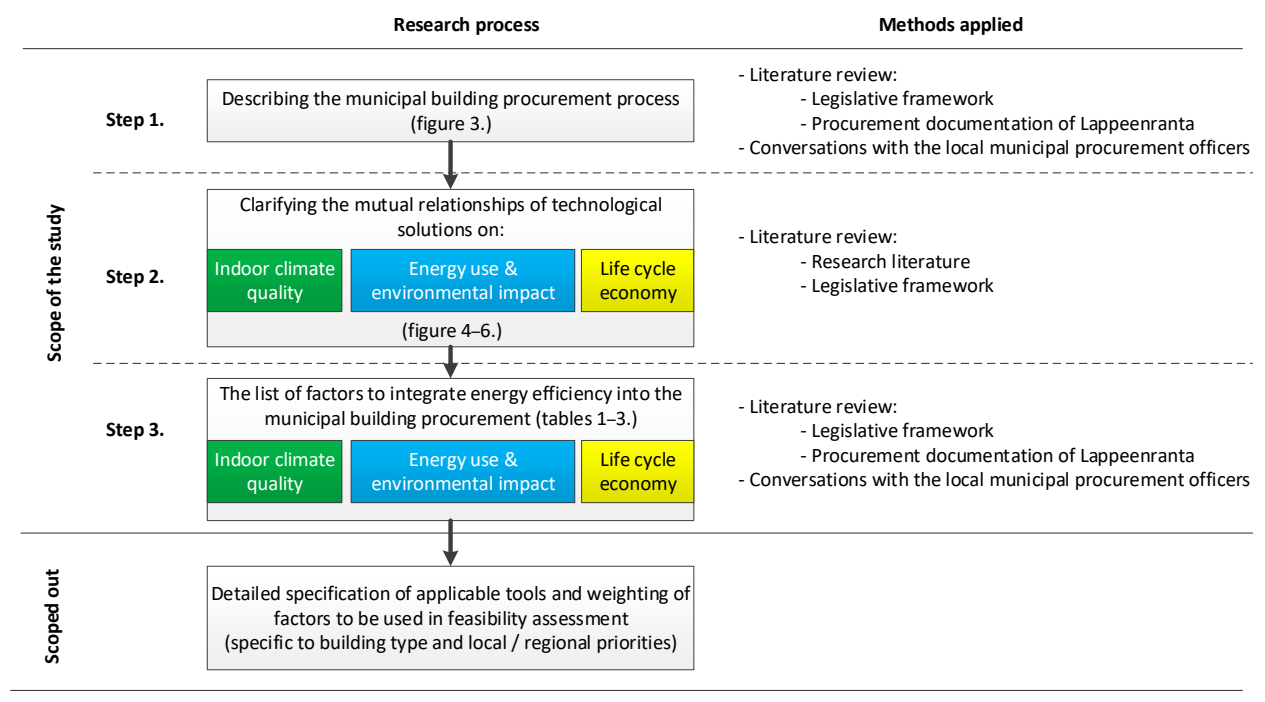

Figure 2. The research process and applied methods.

The relationships between indoor climate quality, energy use (and GHG emissions), and the life cycle economy were described with a review of the relevant research literature and the regulations. Based on the literature review, the design-related factors influencing these three aspects were clarified with figures to ensure the ability of the municipal building department to demand energy efficient solutions in the critical phases of the design. The findings were further structured into the list of factors that need to be considered in the feasibility assessment of alternative design solutions. The structure of the list of factors was developed based on discussions with the local procurement officers involved in the Myllymäki kindergarten procurement project. The paper does not present detailed specifications of tools and weighting of factors to be applied in the feasibility assessment, as these have to be chosen on project-specific basis. Versatility of municipal building types and different local and regional priorities make weighting of factors and tools to be applied difficult to predefine.

\section{Results: Integrating Energy Efficiency into the Municipal Building Procurement Process}

\subsection{Describing Municipal Building Procurement Process-An Energy Efficiency Perspective}

As the manager of the building procurement project, the municipal building department is the head responsible for the integration of energy efficiency into the building procurement process. The building department is involved in every step of the procurement process, and the building department's ability to affect the outcome is high. In general, procurement process follows the common framework by the EU and the national procurement legislation, while also some municipality-specific adaptation differences exist [36-40]. The municipal building procurement process is described in Figure 3.

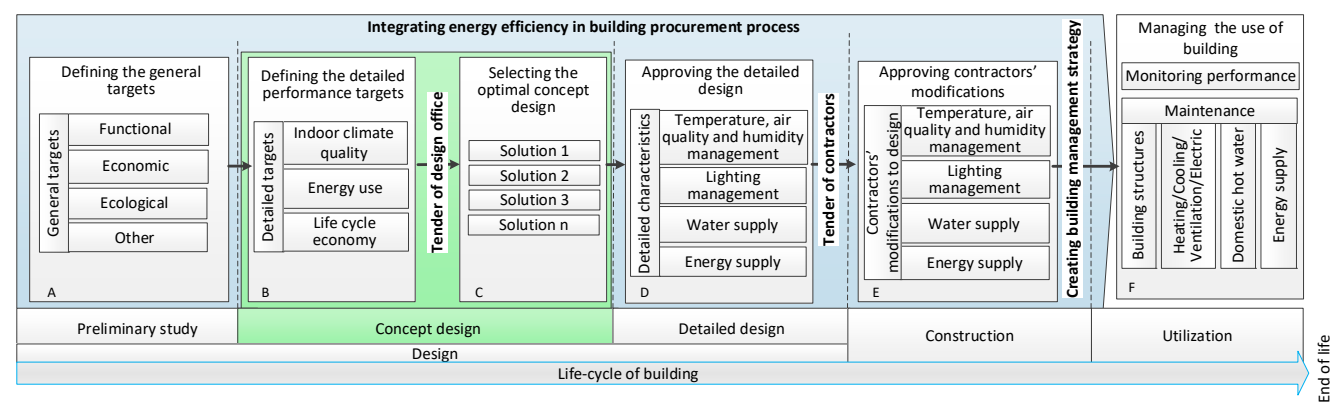

Figure 3. The municipal building procurement process from the municipal building departments' perspective, a Finnish example. A-F order of the process phases. Based on $[2,5,7,10,14,36-46]$. 
In the preliminary study, the municipal building department in co-operation with the actual users establishes the general performance targets for the building project (A in Figure 3) $[2,7,10]$. The performance targets can cover the functionality (i.e., indoor climate quality and purpose of use of spaces) as well as the economic and ecological performance targets $[10,20,36]$. The national building codes define the minimum performance requirements [36]. The specific requirements of the end user have to be accounted for while establishing the performance targets [10,36].

The concept design (highlighted with green in Figure 3) is the most decisive stage of the building's procurement process form the perspective of the life cycle performance [10]. At the beginning of the concept design, the municipal building department defines more detailed targets for the performance of the building (B in Figure 3) [10]. Detailed performance targets can include specific energy use performance class (in Finland classes A-G), indoor climate quality class (in Finland classes S1-S3), GHG emission reduction targets, and the life cycle economy [10]. Later, the building department carries out the tendering of designers who plan the building $[7,10,20]$. Energy efficiency targets have to be clearly present throughout the tendering [7,44]. During the tendering of the design work, the building department reviews the received tenders, evaluating the ability of the design offices to fulfill the energy use and other performance targets $[7,41,44]$. The chosen design team proposes alternative concept design solutions to achieve the performance targets. The municipal building department together with the lead designer iteratively defines the one optimal design solution for further development based on a feasibility assessment ( $\mathrm{C}$ in Figure 3). The optimal compromise between different performance targets is sought $[10,20]$. This paper concentrates on clarifying the municipal building department can lead the concept design towards the optimal design solution.

In the detailed design, the lead designer co-ordinates the design process and ensures that all the design elements work together [14]. The design group lead by the lead designer consists of multiple engineers, including the structural designer, the HVAC (heating, ventilation, and air conditioning) designer, the electric designer, and the automation designer. $[10,14]$. Ensuring that the proposed design solution meets the performance targets and the approval of the detailed design is the responsibility of the municipal building department (D in Figure 3) $[10,14,36]$.

The procurement process proceeds with the construction of the building, led by the main contractor $[10,20]$. Ensuring the required expertise of the contractors through tendering is an important task of the municipal building department $[7,41]$. The main contractor ensures that the sub-contractors are aware of the performance targets and that they comply with them [10]. The main contractor may propose some changes to the final selection of the technology [10]. In theory, the proposed alternatives should not compromise the original performance targets. On practice, cheaper solution alternatives with lower quality might be proposed if this benefits the contractor. Co-ordinated by the municipal building department, the lead designer approves the proposed final selections of the equipment ensuring the required quality (E in Figure 3) [10,14]. Here, the impact of the final equipment selection on the performance has to be examined. Also, the energy use, as well as the other performance targets, has to be considered by the building department when establishing a building management strategy and creating the maintenance manual at the end of the construction phase. $[7,10,14]$

The building management strategy directs the appropriate operations and oversees the building's maintenance while it supports efficient energy use and other performance targets $[7,10,14]$. The actual performance of the building in terms of providing the purposed service quality and the life cycle costs has to be monitored against of the performance targets during utilization (F in Figure 3).

\subsection{Defining Energy Efficiency in the Concept Design of the Municipal Building Procurement}

In order to lead the concept design work (the light green in Figure 3) towards energy efficiency, the municipal building department has to be aware of how the indoor climate quality, the energy use, and the life cycle economy are related through technological solutions and energy markets $[15,16,47]$. This chapter shows how the design-related factors influence these three performance aspects in operational environment of the building undergoing major changes. The same color codes are applied 
throughout the all figures of this paper to visualize the indoor climate quality performance (dark green), the energy use performance (blue), and the life cycle economy (yellow). A deeper understanding of the relationship between design solutions and performance allows including all the necessary factors in the feasibility assessment of the alternative design solutions $[15,16,23,24]$. Furthermore, it allows better-informed dialogue between the municipal building department and the lead designer, as the optimal compromise solution is being co-operatively developed.

\subsubsection{The Factors Affecting Energy Use and the Environmental Impact}

Figure 4 presents how technological solutions define the purchase/sales energy balance and the GHG emissions of the building. The purchase and sales balance for energy and fuel is the basis for the energy efficiency feasibility assessment of alternative design solutions [13,47]. The required energy balance parameters include the purchase energy demand, the peak power demand, and the energy sales to the grid [27]. Technological feasibility depends on the local operational environment of the building and its future changes [27]. Future risk free designs need to accommodate the changes in the climate, energy costs, fuel costs, as well as the availability of energy service models and the regulatory constraints over the long term $[26,27]$.

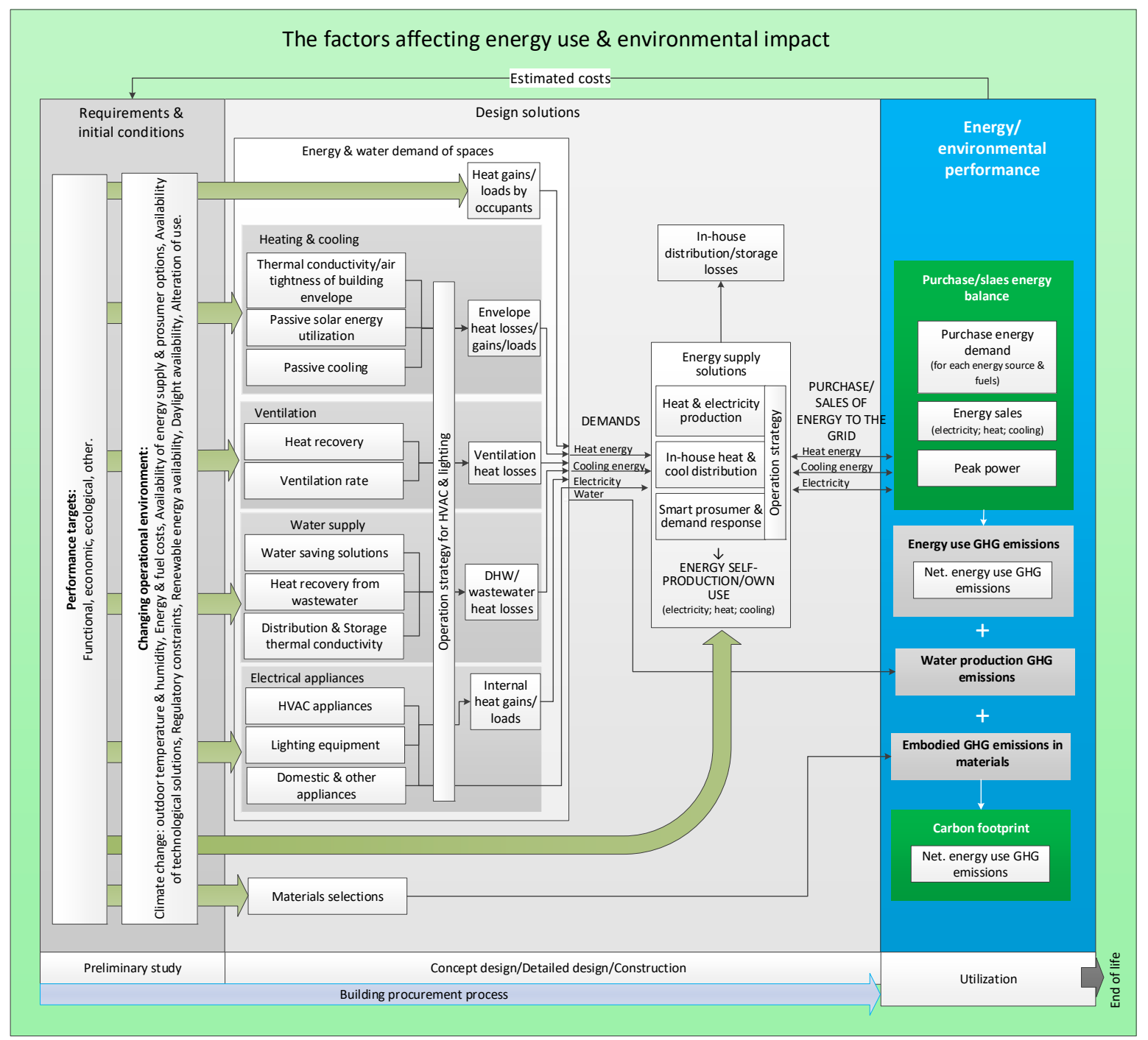

Figure 4. The identification of the factors affecting energy efficiency and the environmental impact of a building. 
The heating energy and the cooling demands of the building are determined by the various heat losses, loads and gains $[2,13,47]$. Reducing heating and cooling demand mitigates the economic risks related to the unpredictable development of energy prices (generation charges, distribution network charges, and tax) [27]. Ventilation is a major heat loss component causing 30-60\% of the energy demand in buildings in industrialized countries [48]. Up to $90 \%$ of the ventilation heat losses can be recovered with modern ventilation heat recovery systems, which reduce the heat demand [48]. Both heat recovery solutions, the ventilation-to-ventilation and ventilation-to-central water heating, can be applied. Energy efficient ground source heat pump-based pre-cooling, pre-heating, and after heating technologies can be applied to reduce the purchase heating energy demand [27]. The demand-based operation strategy and automation can further reduce the heat losses of ventilation, which would reduce the building's heating demand. In addition, heating and cooling demand can be reduced with the building envelope materials that have improved thermal insulation and air tightness $[27,49,50]$. The thermal inertia of buildings' structures can be utilized to cut heating and cooling energy demand peaks [27]. Domestic hot water (DHW) typically consumes between 10 and $20 \%$ of the heating demand for a typical house from the late twentieth century in industrialized countries. [51]. The heating demand of DHW can be reduced through water saving solutions and through minimizing the heat losses from the in-house domestic hot water distribution and the storage system [51,52]. The utilization of passive energy, such as passive solar energy, reduces the heating energy demand of the building [27]. Building envelope solutions, such as window sizing and orientation, as well as potential shadings and blinds, have to be optimized to reduce the purchase energy demand for heating and cooling [53].

Electrical appliances, including lighting, domestic appliances, and HVAC systems, in turn, create the demand for electrical energy [2]. High energy efficiency LED lighting solutions and high energy efficiency class (A+++) domestic appliances strongly reduce purchase electricity demand compared to incandescent bulbs [27]. Window sizing and orientation can be optimized for natural light utilization to reduce the demand for artificial electric lighting [54,55]. Buildings with a lower frame depth usually have better potential to utilize natural light. It is important to optimize illuminous intensity so that the visual performance required by the purpose of the building's use is met. An increase in lighting intensity beyond the optimal level will increase electricity demand without further improving the visual performance. Passive and active thermal radiation blocking solutions can be used to avoid increasing electricity demand for air conditioning [54]. The electrical energy consumption can be reduced by demand-based automation and by the operation strategy of the HVAC and the lighting equipment. Utilizing both system components with increased energy efficiency (frequency controlled fans, pumps etc.), and optimal dimensioning to increase the overall energy efficiency of the system, further reduces the electric energy demand $[10,47,50]$.

The purchase/sales energy balance depends on the applied energy supply technology [13]. Energy supply solutions include centralized and decentralized heating, electricity, or cooling supply based on renewable or non-renewable sources. Minimizing purchase energy and fuel demand mitigates the economic risks related to energy costs [27]. The purchase energy demand can be reduced by efficient energy supply solutions, such as ground source heat pumps. Ground source technology can also be efficiently applied for cooling [55]. Since this technology provides heating throughout the year and scales down the peaks of electricity purchase demand, it mitigates the risks related with increasing peak power charges [27]. Self-produced renewable heating and electric energy reduce the purchase demand for more expensive grid energy $[27,56]$. The surplus of the self-produced heat and electricity can be sold into the local grid by using appropriate real-time metering and bi-directional connection, or it can be stored for future own use [57-61].

Efficient smart prosumer and demand response solutions can be introduced due to the emerged dynamic consumption/sales metering and IoT (Internet of Things) solutions. Smart metering allows the dynamic pricing of purchased and sales energy [58,62]. IoT solutions allow the control of devices' energy use based on real time online energy price data. The smart demand-side management technologies improve the flexibility of the building's energy use by shifting energy use to off-peak 
periods when electricity spot prices are lower $[27,61,63]$. Furthermore, reducing peak power demand mitigates economic risks related to increasing peak power fees [27]. Heat and electricity storages reduce peak power use and maximize the use of self-produced heat and electricity. The electric vehicles can be used as electricity storages through smart charging interfaces. [27,62-64]

The carbon footprint of the design solutions include GHG emissions related to energy use, water production, and emissions embodied in the materials [65]. Emissions of energy use can be estimated based on the purchase/sales energy balance of the building. Accountable emissions include production emissions of purchased energy and fuels used by the building as well as the abated emissions achieved by selling the excess self-produced energy to the grid [27]. Carbon footprint should include emissions embodied in the selected construction materials through production, transportation, installation, maintenance, replacement, demolition, and waste treatment [66]. The GHG emissions need to be estimated to account for the economic impacts of present and future emission-reduction oriented economic steering [2].

\subsubsection{The Factors Affecting Indoor Climate Quality}

Indoor climate quality has to be considered during the feasibility assessment of design solution alternatives when converting energy use into energy efficiency, as in Figure 5. In European countries, around $76 \%$ of the energy consumed in buildings goes to indoor climate comfort control-heating, ventilation, and air conditioning [67]. Energy efficiency can be considered by comparing the service quality that the alternative solution provides with the specific energy input $[15,24,31]$.

Temperature comfort is commonly determined by the indoor temperature level, including temperature profile stability within the building and the actual sensation of the temperature $[68,69]$. Maintaining indoor temperature comfort in Finland is technologically challenging due to the difficult climatic conditions and the effects of climate change. Finland has high annual fluctuations of temperature, with cold winters and increasingly hot summers. In the case of Finland, the dimensioning of heating and cooling solutions has to be based on the outdoor temperature varying from below $-30{ }^{\circ} \mathrm{C}$ in the winter to above $+30^{\circ} \mathrm{C}$ in the summer. Heating demand is high, and cooling demand is growing due to hot summer periods, which are forecasted to become longer and more frequent [70-72]. Heating and cooling demands are also affected by the building envelope design, including thermal insulation and openings $[10,12,64]$. Heating and cooling dimensioning have to account for internal heat loads, such as from occupants as well as from lighting and various electrical appliances [10,12]. The indoor temperature in occupied zones has to be comfortable and temperature comfort should not be disturbed by draught, heat radiation, uneven temperature profiles, temperature fluctuation, or surface temperatures [12]. The temperature profiles can be modified by applying different types of distribution systems for heating, cooling, and ventilation [64]. The actual temperature feeling, in turn, is highly affected by the perceptions of the individuals themselves. The presence of draught increases the sensation of coldness and decreases temperature comfort and should be avoided [12,72]. Sources of draught can be caused by structural air leakages or by supply air distribution issues, such as the velocity of the supply air being too high. The negative sensation of draught can be reduced by increasing the temperature of the air through heating. This, however, leads to an increase in heating energy demand. Furthermore, excess heating decreases the relative humidity of air, which can cause respiratory problems [69]. Structural solutions, the selection and positioning of heating radiators and air distribution devices, and demand-controlled automation all affect temperature comfort [64]. Also, the indoor air humidity level affects the temperature sensation.

Indoor air contains a certain amount of different impurities of both external and internal origin [2]. Among the internal sources of air impurities are those related to respiratory activity and substances released by specific building materials [69]. Ventilation has a major role in managing indoor air pollutant concentration by removing pollutant-containing air and replacing it with cleaner fresh air $[12,69]$. A ventilation operation strategy can include the timing of the ventilation rate in accordance with the actual needs and the control of the ventilation rate with $\mathrm{CO}_{2}$ sensors. An efficient operation 
strategy increases indoor air quality while reducing energy demand. Ventilation equipment and construction materials rated with Finnish M1 emission classification do not emit hazardous substances or unpleasant odors into indoor air and are easily cleansable [73]. Increased ventilation rates two weeks before starting the building's use reduces the indoor air's concentration of impurities derived from the new construction materials [10]. Supply air filters of various efficiency levels are used to prevent impurities from spreading into the building from outdoor air, external loads [12,74]. Filtration is also used for recycled air. An increase in the filtration efficiency, however, commonly leads to higher energy costs due to the increased electricity consumption of the fan [75]. Thus, the filter selection depends on the targeted indoor climate quality and on the outdoor air pollution conditions at the location.

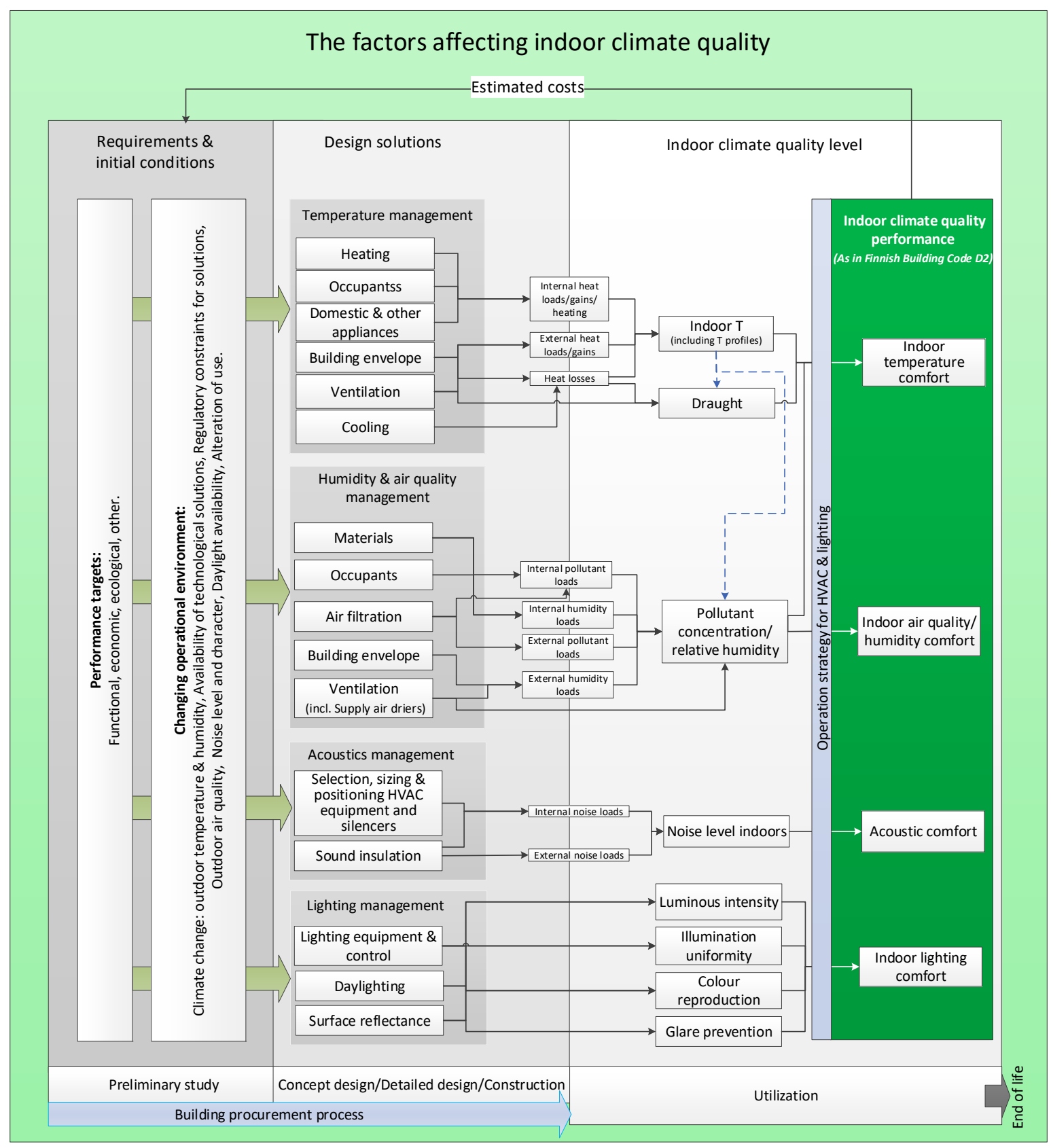

Figure 5. The identification of the factors affecting indoor climate quality in a building. 
The relative humidity has to be maintained so that it does not cause moisture damage to the building's structures or mold growth, which could lead to respiratory symptoms among occupants [12,43]. The condensation of humidity inside the components of the ventilation system also has to be prevented. Low relative humidity, below $25 \%$, might increase allergic reactions and respiratory inflammations [69]. Mold growth can occur with a relative humidity level above 70\% [69]. The optimal relative humidity indoors should be between 25 and 45\% [69]. The humidity loads in the building can be of an internal or external nature. In Finland, the external humidity loads are expected to grow in the future, as rainfall is becoming more frequent and the rising temperatures, caused by climate change, keep the water unfrozen for longer [71,76]. Ventilation is the core mean to remove the excess humidity from the indoor air, which keeps the relative humidity within the optimal level $[10,43,47,64]$. Supply air driers can be applied as part of the ventilation system to reduce external humidity loads. Reducing internal humidity loads decreases the need for excess ventilation, which lowers the building's purchase heating and electricity energy demand [27]. Post-construction structural humidity, released into indoor air, can be reduced by protecting the construction materials from elements during storage and construction [10]. Increased external humidity loads require the careful design of damp proofing and drainage. Building envelope materials with good hygroscopic performance reduce the risks related to the relative humidity due to the ability of these to balance short-term humidity fluctuations $[27,77]$. Appropriate ventilation pressure difference control is important to prevent outdoor humidity from infiltrating the envelope structures, which causes moisture damage [78].

Acoustic conditions are an important element of indoor climate quality. It is necessary to minimize the background noise of both an external and internal origin [79]. Typical noise sources are traffic, different human activities, and internal HVAC machinery [80]. Minimizing sound reverberation is also important, especially in spaces like classrooms [81]. The main solutions for acoustics management include utilizing sound insulation materials, positioning of sound-emitting devices from rooms with high acoustic requirements, and employing sound-absorption materials to reduce reverberation [80,81]. Silencers might be needed to be installed into the ventilation ducts to reduce the duct noise. Duct designs with fewer silencers have lower pressure losses, and the electricity demands of fan are reduced. If possible, positioning the building from significant sources of noise can also positively affect the indoor acoustic conditions.

Indoor lighting conditions are known to affect the productivity of people working in the space [82]. The perceptions of lighting are highly related to individual physiological and psychological characteristics [83]. The color characteristics of light in a space are determined by the spectral power distribution of the light source and by the reflectance properties of the surfaces in the room. The desired uniformity of the illumination depends on the type of activities in the space and the space itself. Lighting that is too non-uniform can cause distraction and discomfort [82]. Illumination uniformity can be affected by the lighting equipment, such as the type of bulb, the positioning and direction of the lighting equipment, and the reflectance of the different surfaces in the space [83]. Daylighting not only reduces the electrical energy demand of artificial lighting but also improves the color reproduction of indoor light, which increases the lighting comfort (Figures 4 and 5) [54,84]. Other factors that contribute to lighting quality include illuminance uniformity, luminance distribution, light color characteristics, and glare $[64,85]$.

\subsubsection{The Factors Affecting the Life Cycle Economy}

Alternative solutions can be compared based on their ability to provide the quality of the indoor climate and GHG emissions reductions from the perspective of life cycle economy $[2,10,36,47,86]$. The life cycle economy assessment of alternative design solutions should include the costs elements presented in Figure 6. 


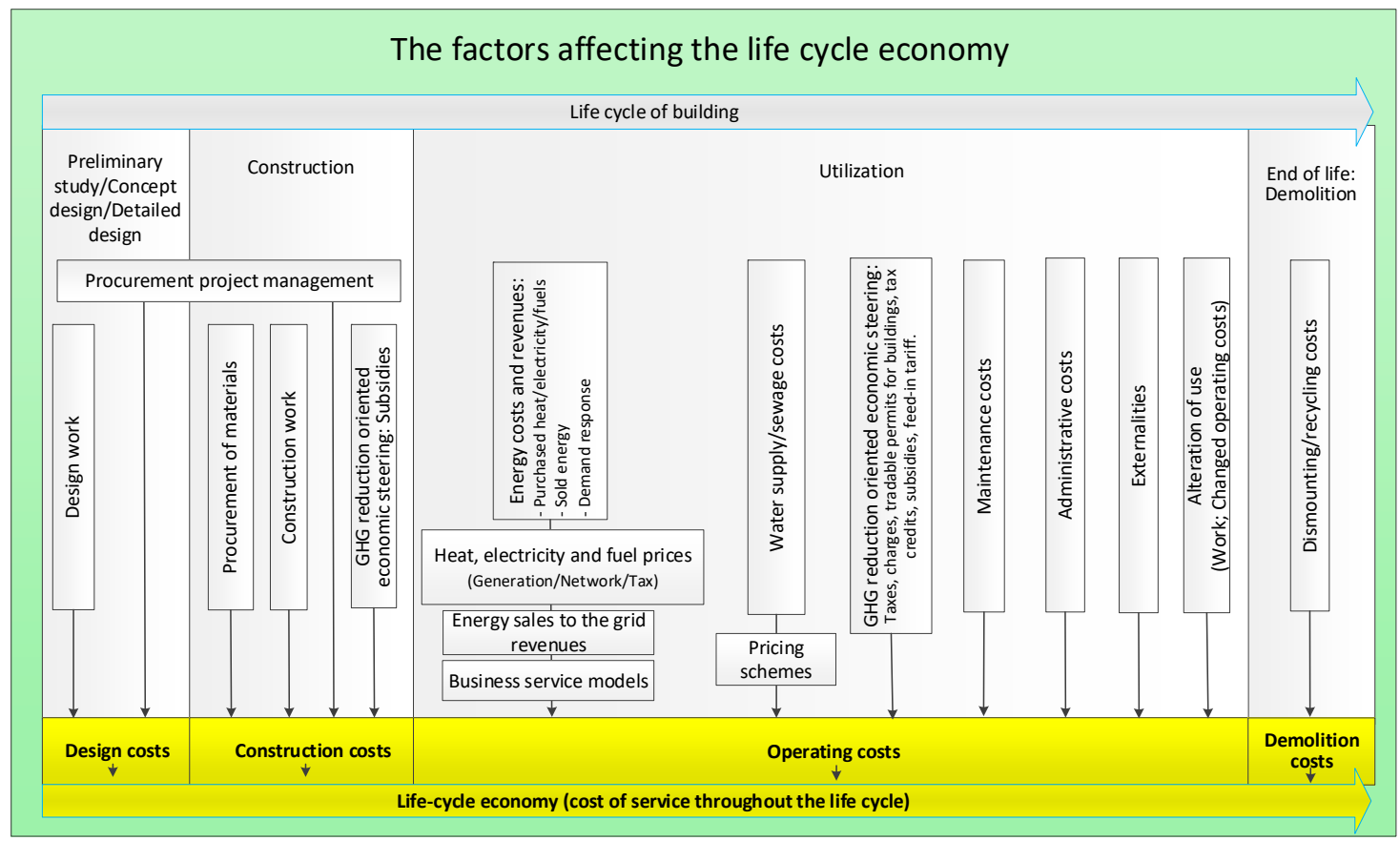

Figure 6. The identification of factors affecting the life cycle economy of a building. GHG: greenhouse gas.

The design phase is where the most important conceptual decisions that will have a crucial impact on the overall life cycle economy of the building are made $[10,27,32]$. The life cycle driven design process has to include the consideration of the economic opportunities and risks provided by the changing operational environment of the building [26-28]. Attention has to be given to the energy sector, as energy expenses dominate the operating costs. Climate change causes an increase in annual average temperatures, in annual temperatures' deviation, and in outdoor humidity [70-72]. These affect building's future costs of heating, cooling, and humidity management. The development of energy prices (generation charges, distribution network charges, and tax), the decreasing costs of decentralized renewable energy technologies (production and storages), emerging service business models and new potential GHGs reduction-oriented economic steering pose new economic risks and opportunities for the building's life cycle economy [26,27]. New economic steering mechanisms for curbing climate change might include taxes, charges, emission trading, or similar tradable permit schemes for real estate. Neglecting these changes might harm the life cycle economy of the building through high operating expenses and low resale value [26,27,87].

Considering opportunities and risks for the building's life cycle economy throughout the design phase is fundamental to defining the "future proofed" energy supply solution in the changing operational environment of the building [26,27]. The development of purchase energy (generation charges, distribution network charges, and tax) prices greatly affects the feasibility of the solutions aimed at energy conservation, energy use flexibility, and renewable energy self-production $[26,27,88,89]$. The future energy bills are affected by increasing maintenance fees, available energy pricing schemes, and increasing peak demand volatility of electrical energy spot prices and peak power charges $[88,89]$. The revenue from energy sales defines the profitability of renewable energy self-production technologies as well as the optimal sizing of production in relation to energy demand. The revenue from energy sales to the grid are affected by energy spot price development and by the available energy sales pricing schemes $[90,91]$. The development of spot prices, peak power fees, and business service models will affect the feasibility of demand response solutions steering energy purchases and sales towards profitable energy market prices and reducing peak power demand $[26,27,92-96]$. 
The municipal building department must be aware of the impact of potential low-carbon oriented economic steering on utilization costs. If introduced, carbon taxes, charges, subsidies, or tradable emission permit schemes for buildings will affect the profitability of energy supply investment in favor of renewable and low-carbon solutions $[27,97]$.

The life cycle driven design has to pay specific attention to indoor climate quality, as it can be monetized in the life cycle economy of service building through the externalities related to increased productivity, reduced sick leaves, and reduced healthcare costs [28,29,87,98].

From the perspective of the life cycle economy, it is important that the potential future changes to the building do not compromise its energy efficiency. These changes might include the changing number of occupants, the alteration of use, such as from office to residential, and the retrofit of new and more advanced technologies [99]. An easily adaptable building requires less alteration work and has lower operating expenses $[99,100]$. The building frame design defines the adaptability of the building for alternative use and the magnitude of the related modification costs [99,101]. In general, deep building frames are more challenging to be converted for residential use, as all the apartments require windows [99]. Alternative purposes of use need to be accounted for during the frame and fenestration design to achieve the required lighting conditions during the alteration easier. Thermal and noise conductivity of the building envelope should be suitable for the building's potential alternative uses $[99,101]$. The sizing and positioning of the ventilation, heating, cooling, and water distribution system components with attention to potential future use would decrease the required modification work and the operating cost improving the building's life cycle economy [101]. Modification costs can also be reduced by leaving space and lead-through reservations for the future duct, pipe, and cable work required by altered use [27]. Technological development constantly produces new and more energy efficient building solutions to the market. At the same time, the updating of building codes narrows the applicability of the current basic solutions during capital renovations. Space, technological, and lead-through reservations would enable the more economical retrofit of novel advanced technologies in the future, as these become feasible or required. [27].

\subsection{The Identification of the Optimal Compromise Design Solution during the Concept Design}

The optimal compromise solution has to be identified by assessing the ability of the alternative solutions to provide sufficient indoor climate quality and to reduce GHG emissions with efficient use of invested public money. As the leader of the construction or renovation project, the municipal building department in co-operation with the lead designer can iteratively identify the optimal design solution following the order presented in Figure 7.

After considering the municipal building departments' targets, the alternative design solutions are proposed for the building department to choose from. The iterative feasibility assessment of the proposed solutions is conducted. The alternative solutions providing the same or different indoor climate quality class can be included into the energy efficiency assessment. The indoor climate quality performance should include temperature comfort, air quality, humidity comfort, acoustics, and lighting. To assess energy efficiency, the solution-specific purchase and sales energy balances are estimated. The estimates should include purchase energy demand and energy sales to the grid for heating, cooling, electricity, and fuels, as well as the peak power demand. At this point, the GHG emissions are also estimated based on the building's energy balance and the specific emission factors of the energy production technologies used. The design-specific life cycle economies can now be suggested based on the purchase/sales energy balance and the GHG emissions. The economic assessment includes future risks and opportunities related to the energy pricing, the economic GHG emission reduction-oriented economic steering and the alterations of the building's use. Externalities in the form of working productivity and sick leaves should also be considered. The municipal building department considers the ability of the solutions to provide indoor climate quality and GHG emission reductions from the perspective of the life cycle economy. Original performance targets and design solutions can be revised until the optimal service quality level (indoor climate and GHG emissions) for the public 
money invested is found. The optimal compromise solution highly depends on what weight the building department choses to give to indoor climate quality, energy use (and GHG emissions) and life cycle economy.

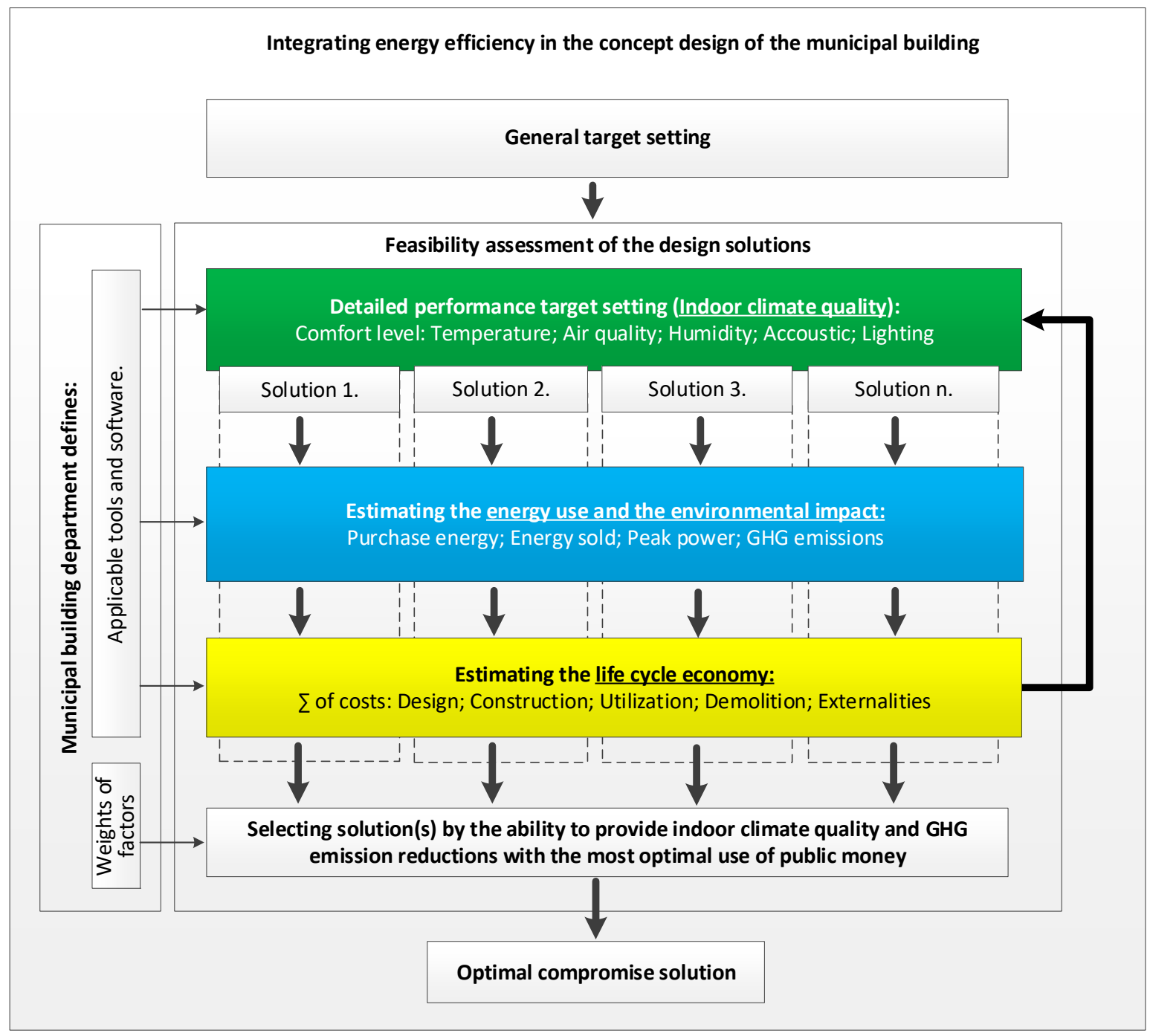

Figure 7. The identification of the optimal compromise design solution during the concept design.

\subsection{The Energy Efficiency Responsibilities in the Concept Design of the Municipal Building}

Figures 8-10 structure the findings of this study into a list of energy efficiency factors and clarify the responsibilities to integrate energy efficiency into the concept design of the municipal building procurement process. Same color codes are applied for the indoor climate quality performance, the energy use performance, and the life cycle economy as in Figures 2-7. 


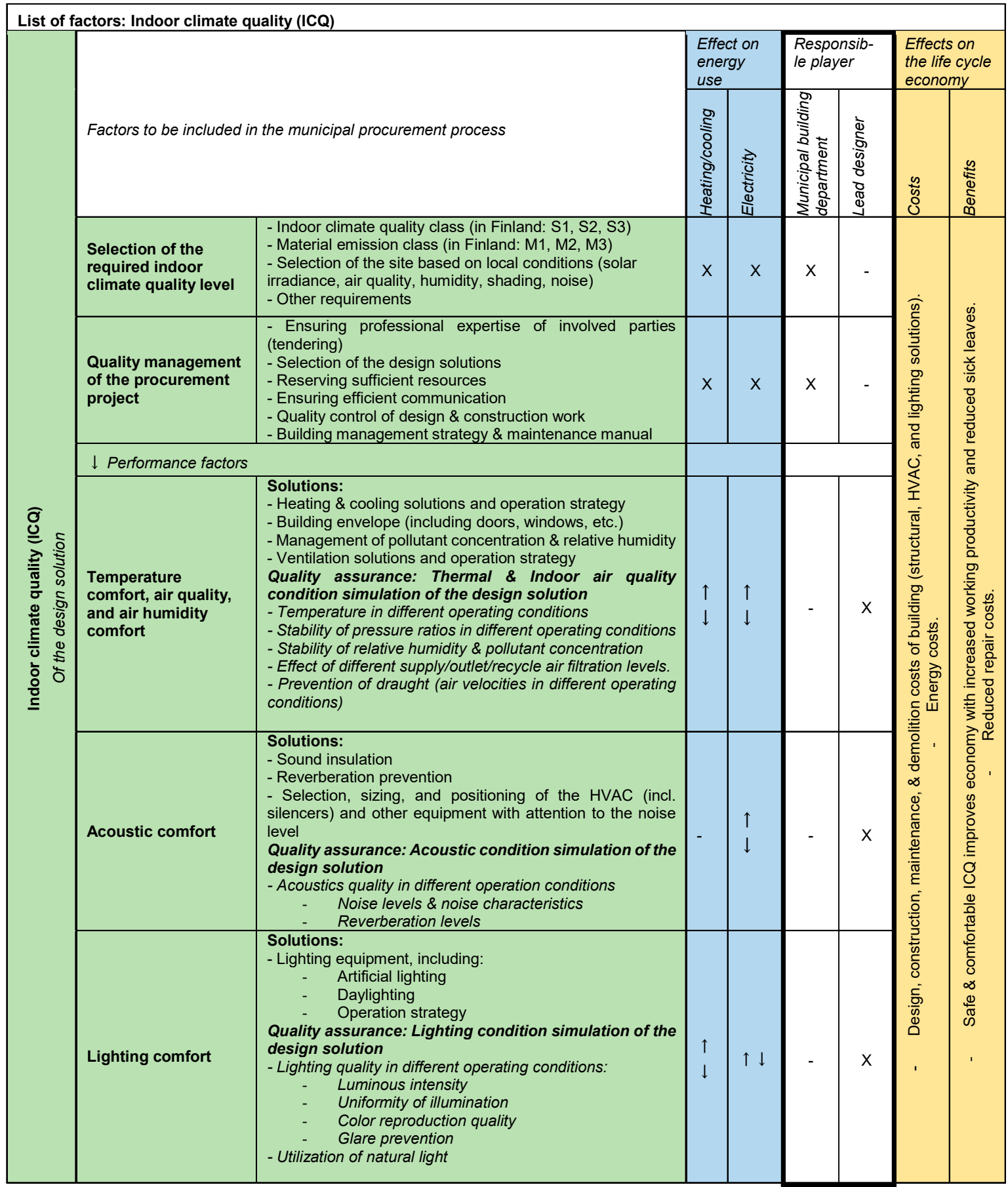

Figure 8. The energy efficiency responsibilities in the design of the municipal building: Indoor climate quality. Based on $[10-14,36,41,43,46,47,69,73,74,78-80,82-85]$. 


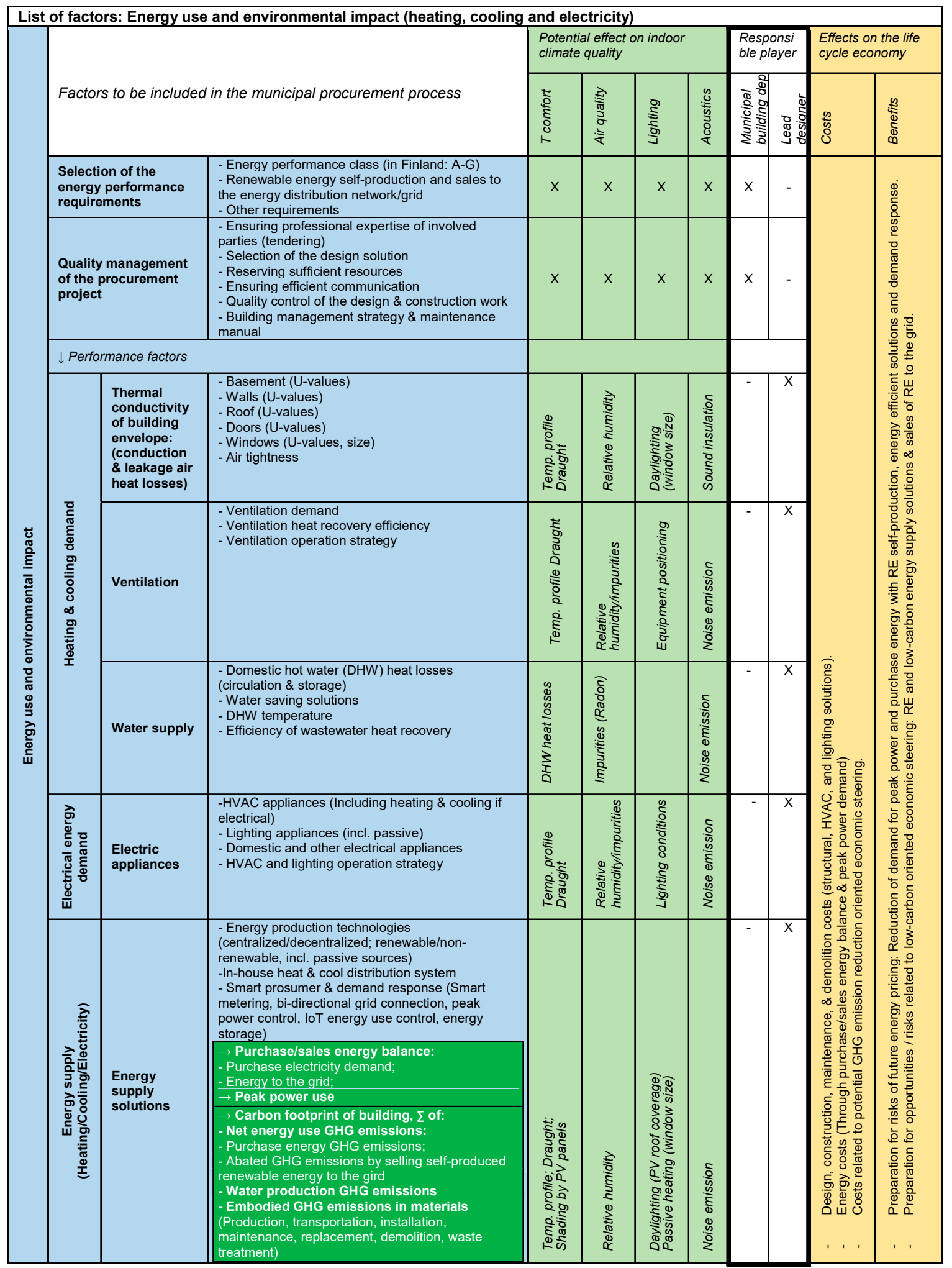

Figure 9. The energy efficiency responsibilities in the design of the municipal building: Energy use and the environmental impact of a building. Based on $[10-14,27,36,41,43,46,47,50,53-59,65,67,79]$. 


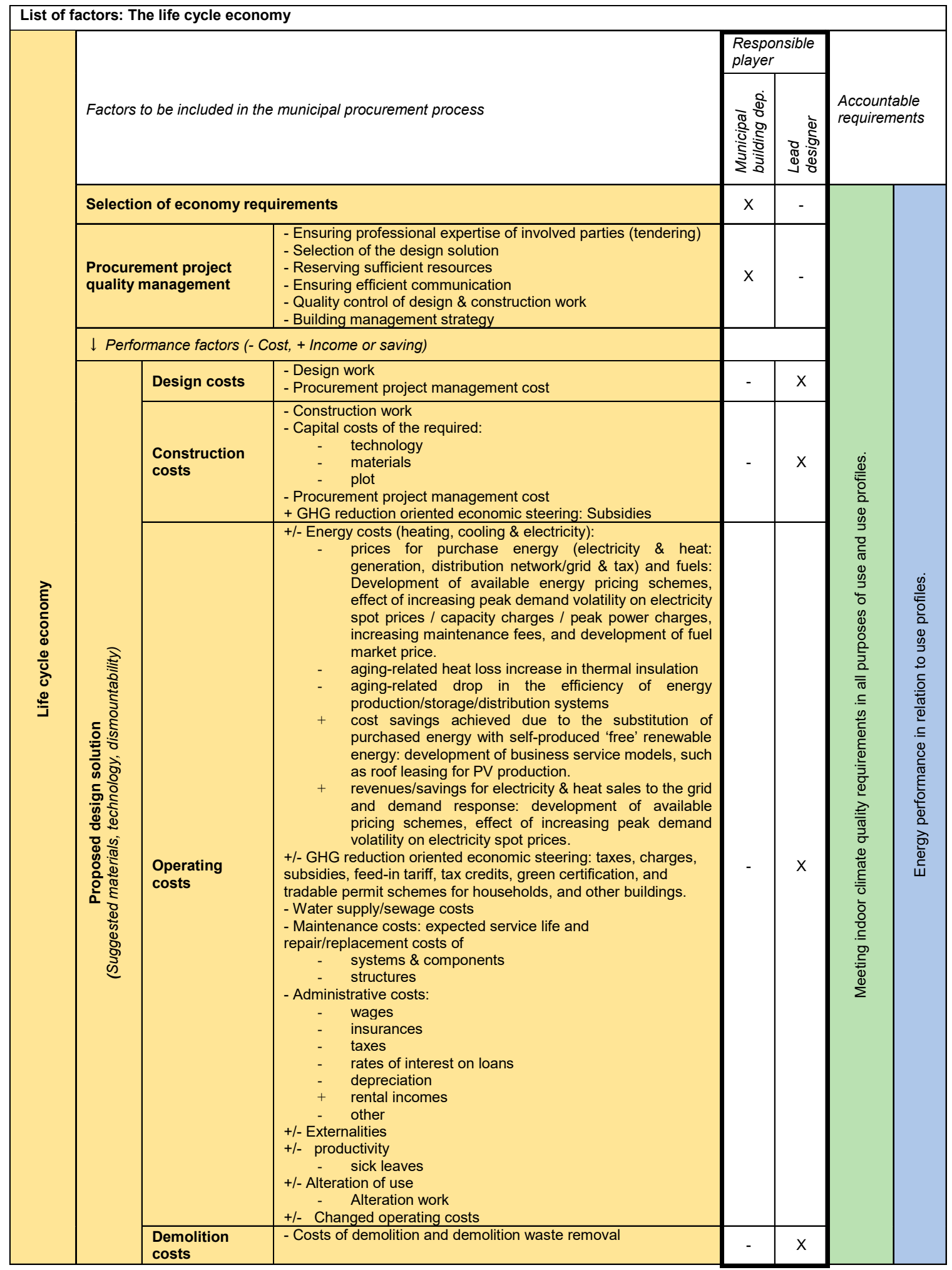

Figure 10. The energy efficiency responsibilities in the design of the municipal building: The life cycle costs of a building. Based on $[10,11,14,27,32,36,41,46,47,86,87,92,98]$. 
This list of energy efficiency factors can be applied during the concept design of the building when the municipal building department together with the lead designer is seeking the design solution providing the optimal value for public money. The list of energy efficiency factors should be used when assessing the performance of the solutions to provide indoor climate quality and GHG emission reduction from the perspective of the life cycle economy in the changing operational environment of the building. Clarifying the energy efficiency factors and the responsibilities, the list contributes to more informed decision-making process.

The list of energy efficiency factors structure and clarify the factors affecting indoor climate quality, energy use (and environmental impact), and the life cycle economy, as identified in Figures 4-6. The connections between indoor climate quality, energy use, and the life cycle economy are presented at the factor level in order to promote energy efficiency through integrated building design solutions (Figures 8-10). The possible direction of the impact of indoor climate quality factors on heating energy, cooling, and electricity consumption are described with arrows in Figure 8. Figure 9 presents the potential effects of the energy use factors on indoor climate quality by means of a checklist and descriptions. If checked, the factors may have a positive or negative effect on the indoor climate quality. Figures 8 and 9 also explain how indoor climate quality and energy use performance factors affect the life cycle economy of the building. The costs and life cycle economic benefits achievable through the building design are explained with emphasis to the changing operational environment of the building. The life cycle cost elements required to be included in feasibility assessment of design solutions are presented in Figure 10.

It is for the municipal building department to decide how much weight each factor should be given and what are the most appropriate tools to be used in the feasibility assessment. Selection of tools and weighting of factors has to be done case-specifically based on the building type and the local and regional priorities. When applying the list of factors the building department demonstrates the applied energy efficiency factors, the chosen weights, and the responsibilities increasing transparency of the decision-making process.

The main responsible actors for the integration of the performance-specific factors into the concept design of the municipal building are defined in Figures 8-10. The importance of roles of the municipal building department and the lead designer in achieving energy efficiency performance are highlighted. The building department steers the project and is responsible to clearly establish the performance targets and ensure that all project partners have sufficient and timely information and resources to achieve the targets. The lead designer, by coordinating the consortium of sub-designers (structural, electric, ventilation, heating, automation, DHW), is responsible to deliver the design that complies with the energy efficiency performance targets.

A wide range of commercial and free software, tools, and methods can be applied by the designer to estimate the indoor climate, the energy use, and the life cycle economy of the design solutions. Energy simulation software can be utilized to assess the purchase/sales energy balance and the peak power demand. Life cycle cost modeling tools can be helpful with the complex life cycle economy estimations. The applied method should be chosen based on the case-specific modeling complexity and precision requirements.

\section{Discussion and Conclusions}

This paper clarifies how the municipal building department can lead the design towards energy efficiency and a high quality indoor climate, which is life cycle cost-effective and complies with the international and national targets and regulations. Specific emphasis is put on the concept design phase of the building's procurement process. The paper describes the relationship between indoor climate quality, energy use (and GHG emissions), and the life cycle economy from the perspective of design-related factors. The paper presents the list of energy efficiency factors that need to be considered in the municipal building procurement process. The list of factors can be applied during the concept design of the building when the municipal building department together with the lead designer is 
seeking a design solution providing the optimal value for public money. The responsibilities for integrating energy efficiency into the municipal building procurement process are clarified in the list of factors. The presented approach contributes to making the procurement and decision making process more transparent.

The public procurements have to provide the taxpayers the required quality service (indoor climate quality and GHG emission reductions) with the most optimal use of public money. The actual cheapest solutions, however, is not the one with the smallest investment costs. Selecting a design solution has to be based on solution's ability to provide indoor climate quality and GHG emission reductions from the perspective of the life cycle economy. The solution with the optimal compromise between indoor climate quality, the energy use performance, and the life cycle economy has to be defined. Procurement practices should not prevent the selection of the solutions with improved life cycle performance because, for example, of an undersized investment budget. Traditional procurement practices need to be revised in case they do not allow the selection of the optimal solution based on quality and cost.

New economic elements have to be included into the life cycle cost examination of alternative design solutions to achieve those with lower risks related to utilization costs and those with improved resale value preservation. In order to identify the sustainable "future proofed" solution, the feasibility assessments have to consider changes in the operational environment of the building. Considerable changes include the availability of service solutions, the future development of energy pricing, and the potential GHG reduction-oriented economic steering. This research contributes to rising the recognition of smart building solutions that improve energy efficiency. Thus, the research is in line with the smart readiness indicator initiatives of the European Commission.

Energy use during building's operation currently form the biggest share of the building's carbon footprint. However, the share of GHG emissions embodied in construction materials in building's carbon footprint is increasing as we move towards more energy efficient construction and lower emission energy production. In the future, material selection will play increasingly important role in low-carbon building design.

The responsibilities of the players involved in the procurement project have to be defined clearly by the municipal building department (client). No gaps in the chain of responsibility should exist. The building department steers the project and is responsible to clearly establish the energy efficiency targets and ensure that all project partners have sufficient and timely information and resources to achieve the targets. The overall control of design production is the responsibility of the lead designer. The lead designer is responsible to convey the performance targets and preferences of the client to consortium of sub-designers (structural, electric, ventilation, heating, automation, and DHW). The lead designer has to be aware about the progress of sub-designs and to coordinate the design work so that the final result complies with the energy efficiency targets. The building department choses the optimal concept design from the options proposed by the designers and approves the detailed design. Systematic and well-timed communication between the building department and the lead designer is important, especially during the concept design. The performance requirements have to be clearly communicated to the lead designer by the building department. To support the building department's decision-making the lead designer has to provide the information regarding the progress of design and its implications on the building's life cycle performance. Interpreting the results of energy efficiency assessment as presented in this approach require specific expertise in the field of construction technology, energy technology, indoor climate technology, automation and the economy. Tasks exceeding expertise of the municipal building department should be outsourced to a professional construction consultant experienced in the field, which can create new business opportunities for consulting companies and can provide new jobs. Outsourcing the tasks does not reduce the responsibility of the building department in the project. The municipal building department carries the final responsibility to provide the building with the functionality to offer the service required by the client, municipality, and taxpayers. 
This research describes what factors are necessary to consider in energy efficiency assessment; however, it does not define in detail the actual tools or mathematical methods to be used in the assessments. The optimal method should be chosen based on the modeling complexity and precision required by the building type in question. Assessment will require making assumptions regarding the future development of the building's operational environment, including energy fees, transmission fees, peak power fees, energy taxation, GHG reduction-oriented economic steering, and climatic conditions. Since the future development of these issues is never certain, the assessment will always include some subjectivity. The outcome of the assessment will also strongly depend on the applied weighting of the factors. The freedom to decide the weight of criteria for optimization is left for the municipal building department. Factors affecting indoor climate quality, energy use (and GHG emission reductions), and the life cycle economy have to be weighted based on the building type and reflecting the local and regional priorities. The procedure can be applied universally during a municipal building procurement process; however, some country- and municipality-specific adaptations are required. Country-specific building standards and procurement regulations and practices have to be accounted for while applying the presented procedure. Besides, procurement procedures applied by different municipalities vary somewhat even within the same country. As the roles and responsibilities of the municipal building department and other project partners in the building procurement project vary in different countries and municipalities, they should be verified on a case-by-case basis. Case-specific energy efficiency and other targets, as well as the available resources, have to be taken into account. Also, attention is required on the effect of the local climatic conditions on energy use and indoor climate quality. For example, the significance of heating and cooling in the overall energy consumption of a building differs remarkably between southern and northern countries. The procedure can be adapted for use in private building procurement projects as well, if the differences in the procurement procedures, roles, and targets are accounted for. The presented procedure can be applied alone or alongside existing labeling systems supporting them, such as LEED or BREEAM.

The town of Lappeenranta integrated the presented approach into their building procurement practices initiating a dialogue regarding energy efficiency between the municipal building department and other stakeholders in building procurement. This dialogue provides a good basis for the further development of energy efficiency management procedures and the introduction of new innovative methodologies into everyday practice. The procedure should be updated continuously based on new evolving knowledge and technological development. In addition, the scope of the procedure can be expanded further to cover renovation projects.

Author Contributions: Conceptualization, M.V., K.G., M.L. and R.S.; Methodology, M.L.; Validation, M.V., S.H. and M.L.; Investigation, M.V.; Writing-Original Draft Preparation, M.V.; Supervision, M.L., R.S. and K.G.; Funding Acquisition, M.L.

Funding: This research was done as a part of the 'Innovatiivisuutta julkisiin investointeihin' (Innovative Public Investments) research project, which is funded by the European Regional Development Fund (ERDF), the town of Lappeenranta, and the Waste Treatment Company of South Karelia (EKJH). Grant number: A32168. We gratefully acknowledge this funding support.

Conflicts of Interest: The authors declare no conflict of interest.

\section{References}

1. EC (European Commission). Buildings. 2017. Available online: https://ec.europa.eu/clima/citizens/eu_en (accessed on 28 September 2017).

2. EC (European Commission). Green Public Procurement Criteria for Office Building Design, Construction and Management. 2016. Available online: http:/ / ec.europa.eu/environment/gpp/pdf/report_gpp_office_ buildings.pdf (accessed on 28 September 2017).

3. EC (European Commission). Energy. 2050 Energy Strategy. 2017. Available online: https://ec.europa.eu/ energy/en/topics/energy-strategy/2050-energy-strategy (accessed on 31 January 2017). 
4. EC (European Commission). Energy Efficiency Directive. 2018. Available online: https://ec.europa.eu/ energy/en/topics/energy-efficiency/energy-efficiency-directive (accessed on 31 January 2017).

5. EUR-Lex. Directive of the European Parliament on the Energy Performance of Buildings. 2010/31/EU. 2018. Available online: https:/ / eur-lex.europa.eu/legal-content/EN/TXT/HTML/?uri=CELEX:32010L0031\& from=EN (accessed on 10 March 2018).

6. Parviainen, J. Kuntien ja Maakuntien Ilmastotyön Tilanne 2015 [The State of the Climate Work in Municipalities 2015]; Kuntaliitto: Helsinki, Finland, 2015; ISBN 978-952-293-335-5.

7. TEM (Ministry of Employment and the Economy). Energiatehokkuus Julkisissa Hankinnoissa (In English: Energy Efficiency in Public Procurements). 2017. Available online: https:/ /www.motiva.fi/files/10919/Tyo_ja_elinkeinoministerion_ohjeet_Energiatehokkuus_julkisissa_hankinnoissa.pdf (accessed on 1 March 2017).

8. Jätteenmäki, A. Opinion of the Committee on the Environment, Public Health and Food Safety for the Committee on Industry, Research and Energy on the proposal for a directive of the European Parliament and of the Council amending Directive 2010/31/EU on the energy performance of buildings. Eur. Parliam. 2017. Available online: http:/ / www.europarl.europa.eu/sides / getDoc.do?pubRef=- / /EP / /TEXT+REPORT+ A8-2017-0314+0+DOC+XML+V0/ /FI (accessed on 2 August 2018).

9. Rava, Rakennuttajatjavalvojat ry (Association of builders and supervisors). Käsitteitä (In English: Terminology). 2017. Available online: https://rakennusvalvojat.fi/yleista/kasitteita/ (accessed on 29 September 2017).

10. RIL (Finnish Association of Civil Engineers). RIL 249-2009 Matalaenergiarakentaminenasuinrakennukset (In English: Low-Energy Construction, Residential Buildings), 2nd ed.; Suomen Rakennusinsinöörien Liitto RIL ry; Saarijärven Offset Oy: Helsinki, Finland, 2009; ISBN 978-951-758-517-0.

11. RIL, (Finnish Association of Civil Engineers). Rakennuttajat. RIL Database 2017. Available online: http:/ / www.ril.fi/ fi/ patevyydet/rakennuttajat-rap-ja-raps.html (accessed on 29 September 2017).

12. MotE (Ministry of the Environment). The Decree of the Ministry of the Environment (on Indoor Climate and Ventilation). 2017. Available online: https:/ /www.finlex.fi/fi/laki/alkup/2017/20171009 (accessed on 25 July 2018).

13. MotE (Ministry of the Environment). The Decree of the Ministry of the Environment (on Energy Efficiency of Buildings). 2017. Available online: https://www.finlex.fi/fi/laki/alkup/2017/20171048 (accessed on 25 July 2018).

14. Rakennustieto (Building Information Group). Pääsuunnittelija ja suunnittelun johtaminen rakennushankkeessa (In English: Lead Designer and Leading the Design Process in the Construction Project). Rakennustietosäätiö 2010. Available online: https: / / www.rakennustieto.fi/Downloads/RK/RK100202.pdf (accessed on 19 June 2017).

15. Sparks, D. Exploring Public Procurement as a Mechanism for Transitioning to Low-Carbon Buildings. Ph.D. Thesis, Queensland University of Technology, Brisbane, Australia, 2018.

16. Carlssona-Kanyama, A.; Carlsen, H.; Dreborg, K.-H. Barriers in municipal climate change adaptation: Results from case studies using backcasting. Futures 2013, 49, 9-21. [CrossRef]

17. Sparrevik, M.; Wangen, H.F.; Fet, A.M.; Boer, L.D. Green public procurement-A case study of an innovative building project in Norway. J. Clean. Prod. 2018, 188, 879-887. [CrossRef]

18. Rakennustieto (Building Information Group). Rakennusprojektin johtaminen (In English: Leading the Construction Project). Rakennustietosäätiö, Finland. Available online: https://www.rakennustieto.fi/ Downloads/RK/RK060501.pdf (accessed on 6 February 2019).

19. Kim, J.; Goodwin, C.; Kim, S. Communication Turns Green Construction Planning into Reality. J. Green Build. 2017, 12, 168-186. [CrossRef]

20. Morledge, R.; Smith, A. Building Procurement, 2nd ed.; John Wiley \& Sons: Hoboken, NJ, USA, 2013; ISBN 978-111-849-369-4.

21. Mikucioniene, R.; Martinaitis, V.; Keras, E. Evaluation of energy efficiency measures sustainability by decision tree method. Energy Build. 2014, 76, 64-71. [CrossRef]

22. Sorell, S. Reducing energy demand: A review of issues, challenges and approaches. Renew. Sustain. Energy Rev. 2015, 47, 74-82. [CrossRef]

23. Tang, Z. An Integrated Life Cycle-based Viable Procurement System to Enhance the Success Level of Sustainable Building. Ph.D. Thesis, The HKU Scholars Hub, Hong Kong, China, 2017. 
24. Trianni, A.; Cagno, E.; De Donatis, A. A Framework to Characterize Energy Efficiency Measures. Appl. Energy 2014, 118, 207-220. [CrossRef]

25. Vidmar, K. Importance of Finding and Defining Energy Conservation Measures. Strateg. Plan. Energy Environ. 2010, 30, 45-63. [CrossRef]

26. Georgiadou, M.C. Future-Proofed Energy Design Approaches for Achieving Low-Energy Homes: Enhancing the Code for Sustainable Homes. Buildings 2014, 4, 488-519. [CrossRef]

27. Vinokurov, M.; Grönman, K.; Kosonen, A.; Luoranen, M.; Soukka, R. Updating the Path to a Carbon-Neutral Built Environment-What Should a Single Builder Do. Buildings 2018, 8, 112. [CrossRef]

28. Becchio, C.; Corgnati, S.P.; Orlietti, L.; Spigliantini, G. Proposal for a modified cost-optimal approach by introducing benefits evaluation. Energy Procedia 2015, 82, 445-451. [CrossRef]

29. Gvozdenović, K.; Zeiler, W.; Maassen, W.H. Towards nZEBs in 2020 in the Netherlands 2014. In Proceedings of the World Renewable Energy Congress 13 (WREC XIII), London, UK, 3-8 August 2014; ISBN 978-3-319-17777-9.

30. Barringer, H.P.; Weber, D.P.; Westside, M.H. Life Cycle Cost Tutorial. In Proceedings of the Fifth International Conference on Process Plant Reliability, Houston, TX, USA, 2-4 October 1996. [CrossRef]

31. Bogenstätter, U. Prediction and optimization of life-cycle costs in early design. Build. Res. Inf. 2000, 28, 376-386. [CrossRef]

32. Fuller, S. Life-cycle Cost Analysis (LCCA). Whole Building Design Guide. National Institute for Building Sciences 2010. Available online: http:/ / www.wbdg.org/resources/lcca.php (accessed on 4 May 2015).

33. Sartori, I.; Hestnes, A.G. Energy use in the life cycle of conventional and low-energy buildings: A review article. Energy Build. 2007, 39, 249-257. [CrossRef]

34. Soukka, R. Applying the Principles of Life Cycle Assessment and Costing in Process Modeling to Examine Profit-Making Capability. Ph.D. Thesis, Acta Universitatit Lappeenrantaensis, Lappeenranta, Finland, 2007; p. 275.

35. Yates, W.; Beaman, D. Design Simulation Tool to Improve Product Reliability. In Proceedings of the Annual Reliability and Maintainability Symposium 1995, Washington, DC, USA, 16-19 January 1995.

36. EC (European Commission). A Handbook on Green Public Procurement, 3rd ed.; European Commission: Brussels, Belgium, 2016. Available online: http://ec.europa.eu/environment/gpp/pdf/Buying-GreenHandbook-3rd-Edition.pdf (accessed on 28 December 2017).

37. EUR-Lex. Directive of the European Parliament on Public Procurement. EUR-Lex Database 2014. 2014/24/EU. 2014. Available online: http://eur-lex.europa.eu/legal-content/EN/TXT/?uri=CELEX\% 3A32014L0024 (accessed on 10 March 2018).

38. Finlex. Directive on Changing the Law on Land Use and Construction (In Finnish: Valtioneuvoston asetus maankäyttö- ja rakennusasetuksen muuttamisesta). Finlex Database 2015. 215/2015. Available online: https:/ / www.edilex.fi/data/rakentamismaaraykset/sk20150215.pdf (accessed on 9 November 2017).

39. Finlex. Law on Public Procurement (In Finnish: Laki julkisista hankinnoista ja käyttöoikeussopimuksista). Finlex Database 2016. 29.12.2016/1397. Available online: http://www.finlex.fi/fi/laki/ajantasa/2016/ 20161397? search[type]=pika\&search[pika]=laki\%20julkisista\%20hankinnoista (accessed on 9 February 2017).

40. Finlex. Law on Land Use and Construction (In Finnish: Maankäyttö ja rakennuslaki). 5.2.1999/132. Finlex database 2017. Available online: http:/ / www.finlex.fi/fi/laki/ajantasa/1999/19990132 (accessed on 9 November 2017).

41. Rakennustieto (Building Information Group). Suunnittelu- ja konsultointipalveluiden hankinta (In English: Procurement of planning and consulting servces). Rakennustietosäätiö 2016. Available online: http:/ / docplayer.fi /41122549-Rts-16-60-1-0-suunnittelu-ja-konsultointipalveluiden-hankinta.html (accessed on 29 September 2017).

42. TEM (Ministry of Employment and the Economy). What Are Public Contracts? TEM Database 2016. Available online: http:/ / www.tem.fi/en/consumers_and_the_market/public_procurement (accessed on 10 April 2016).

43. MotE (Ministry of the Environment). The Decree of the Ministry of the Environment (on Humidity Control of Buildings). 2017. Available online: https://www.finlex.fi/fi/laki/alkup/2017/20170782 (accessed on 20 July 2018). 
44. CFCI (Confederation of Finnish Construction Industries). Hankintalainsäädännön soveltaminen (In English: Applying the Procurement Legislation). CFCI Database 2017. Available online: https://www. rakennusteollisuus.fi/globalassets / toimialat/talonrakennus/hyotytietoa-tyomaille/hankintamenettely_ tiivistelma.pdf (accessed on 1 February 2017).

45. Alyami, S.; Rezgui, Y. Sustainable building assessment tool development approach. Sustain. Cities Soc. 2012, 5, 52-62. [CrossRef]

46. Peres Almeida, C.; Ferreira Ramos, A.; Mendes Silva, J. Sustainability assessment of building rehabilitation actions in old urban centres. Sustain. Cities Soc. 2018, 36, 378-385. [CrossRef]

47. Vinokurov, M.; Luoranen, M.; Hammo, S. Methodology for Optimization of Energy Efficiency, Indoor Climate and Economy Targets in Municipal Building Projects. In Proceedings of the Healthy Buildings 2015, Eindhoven, The Netherlands, 18-20 May 2015; ISBN 978-90-386-3889-8.

48. Dodoo, A.; Gustavsson, L.; Sathre, R. Primary energy implications of ventilation heat recovery in residential buildings. Energy Build. 2011, 43, 1566-1572. [CrossRef]

49. Al-Homoud, M. Performance characteristics and practical applications of common building thermal insulation materials. Build. Environ. 2005, 40, 353-366. [CrossRef]

50. Heikkilä, J. Energiatehokas suunnittelu (In English: Energy Efficient Design). Terveys ja talous 2012. Available online: http://www.terveysjatalous.fi/docs/Jari\%20Heikkil\%C3\%A4\%20Terveytt\%C3\%A4\% 20ja\%20teknologiaa.pdf (accessed on 2 December 2016).

51. Meggers, F.; Leibundgut, H. The potential of wastewater heat and exergy: Decentralized high-temperature recovery with a heat pump. Energy Build. 2011, 43, 879-886. [CrossRef]

52. MotE (Ministry of the Environment). The Decree of the Ministry of the Environment (on Water and Sewerage Systems of Building). 2017. Available online: https:/ / www.finlex.fi/fi/laki/alkup/2017/20171047 (accessed on 23 November 2018).

53. DoE (U.S. Department of Energy). Passive Solar Home Design. DoE 2015. Available online: http:/ / energy. gov / energysaver / passive-solar-home-design (accessed on 2 March 2016).

54. Gregg, D. Daylighting. National Institute of Building Science 2017. Available online: http://www.wbdg. org/resources/daylighting.php (accessed on 4 February 2017).

55. Karunathilake, H.; Perera, P.; Ruparathna, R.; Hewage, K. Renewable energy integration into community energy systems: A case study of new urban residential development. J. Clean. Prod. 2016, 173, 1-16. [CrossRef]

56. VTT. Maalämmön ja-viilennyksen hyödyntäminen asuinkerrostalon lämmityksessä ja jäähdytyksessä (In English: Utilization of Ground Source Heat Pump in Heating and Cooling of the Residential Building). Available online: http:/ / www.vtt.fi/inf/pdf/tiedotteet/2010/T2546.pdf (accessed on 5 March 2018).

57. Koroneos, C.; Tsarouhis, M. Exergy analysis and life cycle assessment of solar heating and cooling systems in the building environment. J. Clean. Prod. 2012, 32, 52-60. [CrossRef]

58. Li, D.H.W.; Yang, L.; Lam, J.C. Zero energy buildings and sustainable development implications-A review. Energy 2013, 54, 1-10. [CrossRef]

59. MotE (Ministry of the Environment). Energiatodistusopas 2013 (In English: The Energy Certificate Guide); Minsitry of the Environment: Helsinki, Finland, 2013.

60. Jenkins, D.P.; Patidar, S.; Simpson, S.A. Quantifying Change in Buildings in a Future Climate and Their Effect on Energy Systems. Buildings 2015, 5, 985-1002. [CrossRef]

61. Crosbie, T.; Broderick, J.; Short, M.; Charlesworth, R.; Dawood, M. Demand Response Technology Readiness Levels for Energy Management in Blocks of Buildings. Buildings 2018, 8, 13. [CrossRef]

62. Karnouskos, S. Demand Side Management via prosumer interactions in a smart city energy marketplace. In Proceedings of the 2011 2nd IEEE PES International Conference and Exhibition on Innovative Smart Grid Technologies, Manchester, UK, 5-7 December 2011.

63. Wei, C.; Li, Y. Design of energy consumption monitoring and energy-saving management system of intelligent building based on the Internet of things. In Proceedings of the 2011 International Conference on Electronics, Communications and Control, Ningbo, China, 9-11 September 2011; pp. 3650-3652.

64. Akadiri, P.O.; Ezekiel, A.C.; Olomolaiye, P.O. Design of A Sustainable Building: A Conceptual Framework for Implementing Sustainability in the Building Sector. Buildings 2012, 2, 126-152. [CrossRef] 
65. Bionova Oy. Tiekartta Rakennuksen Elinkaaren Hiilijalanjäljen Huomioimiseksi Rakentamisen Ohjauksessa (In English: The Roadmap to Accounting Carbon Footprint in Steering of Construction); Ministry of the Environment: Helsinki, Finland, 2017.

66. Finnish Standards Association SFS. SFS-EN 15804, Sustainability of Construction Works. In Core Rules for Product Category of Construction Products; Finnish Standards Association: Helsinki, Finland, 2014.

67. Oldewurtel, F.; Parisio, A.; Jones, C.; Gyalistras, D.; Gwerder, M.; Stauch, V.; Lehmann, B.; Morari, M. Use of model predictive control and weather forecasts for energy efficient building climate control. Energy Build. 2012, 45, 15-17. [CrossRef]

68. Säteri, J. Sisäilmasto ja energiatalous (In English: Indoor climate and energy economy). Indoor Air Association of Finland 2014. Available online: http://www.korjausrakentaminen2014.fi/File/626/ sisailmasto-ja-energiatalous-korjrak2014.pdf (accessed on 1 February 2016).

69. IAA (Indoor Air Association of Finland). Sisäilman tekijät (In English: Indoor Air Components). IAA 2008. Available online: http:/ / www.sisailmayhdistys.fi/Terveelliset-tilat/Sisailmasto/Sisailman-tekijat (accessed on 10 November 2016).

70. Climate Guide. Projected Climate Change in Finland. Climate Guide 2018. Available online: https://ilmasto-opas.fi/en/ilmastonmuutos/suomen-muuttuva-ilmasto/-/artikkeli/74b167fc384b-44ae-84aa-c585ec218b41/ennustettu-ilmastonmuutos-suomessa.html (accessed on 23 October 2018).

71. Jylhä, K.; Ruosteenoja, K.; Räisänen, J.; Fronzek, S. Miten Väistämättömään Ilmastonmuutokseen Voidaan Varautua?_Yhteenveto Suomalaisesta Sopeutumistutkimuksesta eri Toimialoilla (In English: How to Adopt to Inevitable Climate Change?); Ministry of Agriculture and Forestry: Helsinki, Finland, 2012; pp. 16-23.

72. Ruosteenoja, K. Temperature and Rainfall Scenarios Based on the Global Climate Models. Sektoritutkimusohjelman ilmastoskenaariot (SETUKLIM) 1. part-Project. Finnish Meteorological Institute 2013. Available online: http:/ /ilmatieteenlaitos.fi/c/document_library / get_file?uuid=c4c5bf12-655e-467a9ee0-f06d8145aaa6\&groupId=30106 (accessed on 23 October 2018).

73. IAA (Indoor Air Association of Finland). Sisäilmastoluokitus (In English: Indoor Climate Quality Classification). IAA 2018. Available online: http://www.sisailmayhdistys.fi/Sisailmayhdistys/ Sisailmastoluokitus (accessed on 10 September 2018).

74. Burroughs, H.E.; Hansen, S.J. Managing Indoor Air Quality, 5th ed.; The Fairmont Press Inc.: Lilburn, GA, USA, 2011; ISBN 0-88173-661-9.

75. Kulmala, I.; Kalliohaka, T.; Kataja, J.; Leppälä, V. Reaaliaikainen tuloilmasuodattimen toimintakunnon mittausjärjestelmä (In English: Real Time Measurement System for Supply Air Filter Functionality). VTT 2015. Available online: http:/ / www.vtt.fi/inf/julkaisut/muut/2015/OA-Reaaliaikainen-tuloilmasuodattimen. pdf (accessed on 29 January 2016).

76. Ruosteenoja, K.; Jylhä, K.; Kämäräinen, M. Climate projections for Finland under the RCP forcing scenarios. Geophysica 2016, 51, 17-50.

77. VTT. Puurakenteiden Kosteustekninen Toiminta (In English: Hygroscopic Performance of Wooden Stucturs). Available online: https:/ / www.vtt.fi/inf/pdf/tiedotteet/1999/T1991.pdf (accessed on 2 March 2018).

78. OfRH (Organization for Respiratory Health in Finland (Hengitysliitto)). Kuiva ja kostea ilma (In English: Dry and Humid Air). Hengitysliitto 2016. Available online: http://www.hengitysliitto.fi/fi/sisailma/ hiukkasmaiset-ja-kaasumaiset-epapuhtaudet/kuiva-ja-kostea-ilma (accessed on 5 June 2016).

79. MotE (Ministry of the Environment). The Decree of the Ministry of the Environment (on Building's Sound Environment). 2017. Available online: https:/ / www.finlex.fi/fi/laki/alkup/2017/20170796 (accessed on 26 July 2018).

80. Paradis, R. Acoustic Comfort. Whole Building Design Guide. National Institute of Building Sciences 2012. Available online: http:/ / www.wbdg.org/resources/acoustic.php (accessed on 19 December 2015).

81. Sala, E.; Viljanen, V. Improvement of Acoustic Conditions for Speech Communication in Classrooms. Appl. Acoust. 1995, 45, 81-91. [CrossRef]

82. Halonen, L.; Tetri, E.; Bhusal, P. Guidebook for Energy Efficient Electric Lighting for Building; Aalto University: Helsinki, Finland, 2010; ISBN 978-952-60-3229-0.

83. Boyce, P.R. Human Factors in Lighting, 2nd ed.; Taylor \& Francis: London, UK; New York, NY, USA, 2003.

84. Sharp, F.; Lindsey, D.; Dols, J.; Coker, J. The use and environmental impact of daylighting. J. Clean. Prod. 2014, 85, 462-471. [CrossRef] 
85. Veitch, J.A.; Newsham, G.R. Determinants of lighting quality I: State of the Science. J. Illum. Eng. Soc. 1998, 27, 92-106. [CrossRef]

86. Pal, S.K.; Takano, A.; Alanne, K.; Palonen, M.; Siren, K. A multi-objective life cycle approach for optimal building design: A case study in Finnish context. J. Clean. Prod. 2017, 143, 1021-1035. [CrossRef]

87. GBC (Green Building Council) Finland. Life-Cycle Cost-The Long-Term Cost Efficiency Indicator. GBC 2017. Available online: http:/ / figbc.fi/en/building-performance-indicators/calculation-guide/life-cyclecost-guide/ (accessed on 29 October 2017).

88. ACEEE (American Council for an Energy-Efficient Economy). Some Utilities Are Rushing to Raise Fixed Charges. That Would Be Bad for the Economy and Your Utility Bill. Available online: https: / / aceee.org/ blog/2014/12/some-utilities-are-rushing-raise-fixe (accessed on 5 October 2018).

89. Brunekreeft, G.; Buchmann, M.; Meyer, R. New developments in electricity markets following large-scale integration of renewable energy. In The Routledge Companion to Network Industries; Routledge: Abington, UK, 2015.

90. EC (European Commission). Digitizing the Energy Sector: An Opportunity for Europe. European Commission 2018. Available online: https://ec.europa.eu/digital-single-market/en/blog/digitisingenergy-sector-opportunity-europe (accessed on 16 March 2018).

91. FLEXe. The Final Report of the Research Project FLEXe (Flexible Energy System). Available online: http:/ / flexefinalreport.fi/content/prosumers (accessed on 21 March 2018).

92. Hong, J.; Zhang, X.; Shen, Q.; Zhang, W.; Feng, Y. A multi-regional based hybrid method for assessing life cycle energy use of buildings: A case study. J. Clean. Prod. 2017, 148, 760-772. [CrossRef]

93. IEA (International Energy Agency). World Energy Investment. 2017. Available online: https://www.iea. org/publications/wei2017/ (accessed on 16 March 2018).

94. Pereira, R.; Figueiredo, J.; Melicio, R.; Mendes, V.M.F.; Martins, J.; Quadrado, J.C. Consumer Energy Management System with Integration of Smart Meters. Energy Rep. 2015, 1, 22-29. [CrossRef]

95. Simola, A.; Kosonen, A.; Ahonen, T.; Ahola, J.; Korhonen, M.; Hannula, T. Optimal dimensioning of a solar PV plant with measured electrical load curves in Finland. Sol. Energy 2018, 170, 113-123. [CrossRef]

96. Vimpari, J.; Junnila, S. Evaluating decentralized energy investments: Spatial value of on-site PV electricity. Renew. Sustain. Energy Rev. 2017, 70, 1217-1222. [CrossRef]

97. Kniefel, J. Life-cycle carbon and cost analysis of energy efficiency measures in new commercial buildings. Energy Build. 2010, 42, 333-340. [CrossRef]

98. Balaban, O.; Puppim de Oliveira, J. Sustainable buildings for healthier cities: Assessing the co-benefits of green buildings in Japan. J. Clean. Prod. 2016. [CrossRef]

99. Gann, D.; Barlow, J. Flexibility in building use: The technical feasibility of converting redundant offices into flats. Constr. Manag. Econ. 1996, 14, 55-66. [CrossRef]

100. Jauhiainen, T.; Rahikka, A. Runkorakenteiden korjausrakentamisen suunnittelu (In English: Planning the Renovation of Building Frame). In RIL 174-4. Korjausrakentaminen 4, Runkorakenteet; Finnish Association of Civil Engineers: Helsinki, Finland, 1988.

101. Koskinen, J. Building's suitability for change of use. Master's Thesis, TUT DPub, Tampere University of Technology, Tampere, Finland, 2016.

(C) 2019 by the authors. Licensee MDPI, Basel, Switzerland. This article is an open access article distributed under the terms and conditions of the Creative Commons Attribution (CC BY) license (http://creativecommons.org/licenses/by/4.0/). 